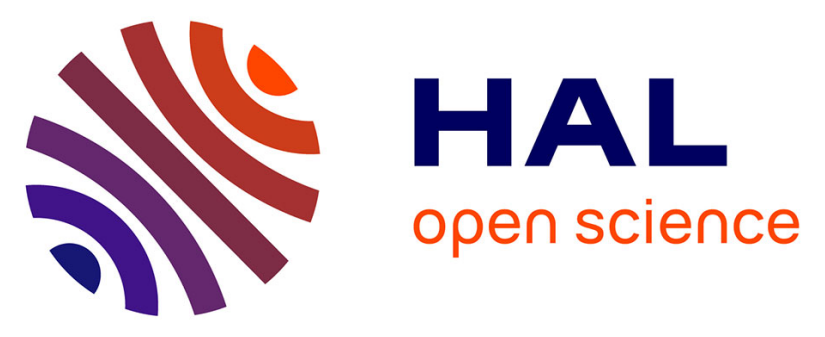

\title{
Modelling the porewater chemistry of the Callovian-Oxfordian formation at a regional scale
}

\author{
Eric C. Gaucher, Philippe Blanc, Frédérique Bardot, Gilles Braibant, \\ Stéphane Buschaert, Catherine Crouzet, Anne Gautier, Jean-Pierre Girard, \\ Emmanuel Jacquot, Arnault Lassin, et al.
}

\section{To cite this version:}

Eric C. Gaucher, Philippe Blanc, Frédérique Bardot, Gilles Braibant, Stéphane Buschaert, et al.. Modelling the porewater chemistry of the Callovian-Oxfordian formation at a regional scale. Comptes Rendus Géoscience, 2006, 338, pp.917-930. 10.1016/j.crte.2006.06.002 . hal-00664798

\section{HAL Id: hal-00664798 https: / hal-brgm.archives-ouvertes.fr/hal-00664798}

Submitted on 31 Jan 2012

HAL is a multi-disciplinary open access archive for the deposit and dissemination of scientific research documents, whether they are published or not. The documents may come from teaching and research institutions in France or abroad, or from public or private research centers.
L'archive ouverte pluridisciplinaire HAL, est destinée au dépôt et à la diffusion de documents scientifiques de niveau recherche, publiés ou non, émanant des établissements d'enseignement et de recherche français ou étrangers, des laboratoires publics ou privés. 


\section{MODELING THE POREWATER CHEMISTRY OF THE CALLOVIAN- OXFORDIAN FORMATION AT A REGIONAL SCALE}

\section{MODELISATION REGIONALE DE LA CHIMIE DES EAUX PORALES DE LA FORMATION DU CALLOVO-OXFORDIEN}

Eric C. Gaucher ${ }^{1, *}$, Philippe Blanc ${ }^{1}$, Frédérique Bardot ${ }^{1}$, Gilles Braibant ${ }^{1}$, Stéphane Buschaert $^{2}$, Catherine Crouzet ${ }^{1}$, Anne Gautier ${ }^{1}$, Jean-Pierre Girard ${ }^{1}$, Emmanuel Jacquot ${ }^{2}$, Arnault Lassin ${ }^{1}$, Gabrielle Negrel ${ }^{3}$, Christophe Tournassat ${ }^{1}$, Agnès Vinsot ${ }^{4}$, Scott Altmann ${ }^{2}$.

${ }^{1}$ BRGM, 3 avenue C. Guillemin, BP 6009, Orléans Cedex 2 45060, France

${ }^{2}$ ANDRA, 1-7 rue Jean Monnet, 92298 Châtenay-Malabry, France

${ }^{3}$ ANTEA, 3 avenue C. Guillemin, BP 6009, Orléans 45061, France

${ }^{4}$ ANDRA, Lab. Meuse/Haute Marne, Cd 960, 55290 Bure, France

* Corresponding author

Tel: 33 (0)2.38.64.35.73; Fax 33 (0)2.38.64.30.62; e-mail address: e.gaucher@brgm.fr

\section{RESUME}

Au sein des études menées par l'ANDRA pour caractériser le Callovo-Oxfordien, la chimie de l'eau interstitielle constitue une thématique clé car elle détermine le devenir dans le temps des matériaux introduit sur les sites de stockage (bentonite, béton, métaux, colis de verre). Elle détermine aussi la spéciation (et donc la mobilité) des radionucléides. La méthode développée dans le cadre du projet THERMOAR permet l'acquisition d'un jeu complet de données pour modéliser la chimie des eaux à partir de carottes de roche. Elle nécessite une étude minéralogique approfondie, un modèle de répartition eau libre/eau liée, des expériences de lessivage, des mesures des ions adsorbés, l'acquisition de constantes d'échange d'ions, la mesure des pressions partielles en $\mathrm{CO}_{2}$. L'ensemble de ces expériences et mesures a été appliqué à des échantillons provenant du site du laboratoire Meuse/Haute-Marne et des forages régionaux de l’ANDRA. On observe ainsi la stabilité régionale d'un grand nombre de paramètres à l'exception d'une diminution de teneur en $\mathrm{Na}$ et $\mathrm{Cl}$ suivant un axe nord-est / sud-ouest passant par le laboratoire. Le modèle d'équilibre eau/roche permet de calculer la composition chimique des eaux interstitielle de la formation. 


\section{ABSTRACT}

In ANDRA's studies to characterize the Callovian-Oxfordian Formation, porewater chemistry is a key topic. Indeed, chemistry determines the durability of the repository materials (bentonite, concrete, metals, nuclear glass) and the speciation (and thus the mobility) of radionuclides. The method developed in the frame of the THERMOAR project enables the acquisition of a complete set of data from core samples to model the porewater chemistry. The method requires a detailed mineralogical study, a model of free water/bound water distribution, leaching experiments, adsorbed ion measurements, ion exchange constant acquisition, and $\mathrm{CO}_{2}$ partial pressure measurements. These experiments and measurements were done on samples from the site of the Meuse/Haute-Marne laboratory and from ANDRA's regional boreholes. The regional stability of a great number of parameters can be observed except for a decrease of the $\mathrm{Na}$ and $\mathrm{Cl}$ concentration following a northeastern/south-western axis passing by the laboratory. The water/rock equilibrium model makes it possible to calculate the chemical composition of interstitial waters of the formation.

Mots-clés : Équilibre eau/argiles, Eau interstitielle, Argilites, Callovo-Oxfordien, ANDRA.

Keywords: clay/water equilibrium, porewater, argillites, Callovian-Oxfordian, ANDRA 
Version française abrégée

\section{INTRODUCTION}

L’Agence Nationale pour la gestion des Déchets Radioactifs (ANDRA) construit un laboratoire de recherche souterrain sur la commune de Bure (NE, France), pour étudier la faisabilité d'un stockage profond de déchets radioactifs au sein de la formation argileuse du Callovo-Oxfordien (COX, $490 \mathrm{~m}$ ). Pour connaître la durabilité chimique des matériaux introduits sur le site (verres, aciers, bétons, barrières ouvragées argileuses, ...) et la mobilité des radioéléments dans cet environnement, il est nécessaire de connaître la chimie des eaux de la formation. Pour répondre à cet objectif, l'ANDRA a carotté un grand nombre d'échantillons au niveau du laboratoire et dans son environnement régional. Ces carottes ont permis d’obtenir un grand nombre de données géochimiques utilisables pour définir la chimie des eaux interstitielles de la formation à une échelle régionale. La littérature scientifique dans ce domaine $[1,2]$ montre que la définition de cette chimie est très difficile. L'extraction de l'eau interstitielle par pressage $[3,4]$, ou l'échantillonnage des eaux en forages spéciaux à chambre sous $\mathrm{N}_{2}$ $[5,6,7]$ génèrent des artéfacts modifiant dans des proportions variables cette chimie, l'oxydation des échantillons étant l'artéfact le plus difficile à maîtriser [4, 8]. Dans le cadre du partenariat BRGMANDRA, une méthode a été développée d'abord au sein du laboratoire de recherche du Mont Terri [9] puis appliquée à Bure. A partir d’un jeu complet de données géochimiques, il est possible de construire des modèles d'équilibre eau/argilite sans ajustement de paramètres. Dans les modèles antérieurs, Bradbury et Baeyens [10] étaient obligés d'estimer la $p \mathrm{CO}_{2}$, Beaucaire et al., [11] négligeaient les argiles $2: 1$ et les réactions d'échange d'ions, ou encore Motellier et al., [12] faisait l’impasse sur les teneurs en sulfates.

\section{SITUATION GEOLOGIQUE}

La zone étudiée par l'ANDRA [13] concerne un bloc structural homogène ceinturé par des accidents structuraux (Fig. 1). Le COX imperméable est recouvert par l’Oxfordien calcaire et le Kimméridgien qui présentent quelques niveaux producteurs en eau. Il surmonte le Dogger peu productif en eau, le Lias qui est imperméable et les formations triasiques qui contiennent des saumures. 


\section{ACQUISITION DES DONNEES EXPERIMENTALES}

Les paramètres utilisés pour construire les modèles sont les suivants : (1) une identification exhaustive des minéraux et une qualification de leur état cristallin (Tableau I) ; (2) une qualification de l'état réduit du système compte tenu de la présence de pyrite et d'une capacité réductrice de la roche en moyenne de 4,7 meq/g (meq d'électrons par g de solide sec) ; (3) une mesure de la teneur en eau (Tableau II) ; (4) une mesure des surfaces spécifiques mouillées par l'eau pour calculer la répartition entre eau libre et eau liée tenant compte des phénomènes d'exclusion anionique $[17,18]$ existant dans les bancs argileux de la formation (Tableau III) ; (5) des expériences de lessivage pour connaître les teneurs en anions dissous (Tableau IV, Fig. 2) ; (6) des mesures de cations adsorbés (Fig. 4) ; (7) l'acquisition des constantes d'échange ionique spécifiques de l'argilite (Tableau VI, Fig. 5) ; (8) la mesure des pressions partielles en $\mathrm{CO}_{2}$ (Fig. 7); (9) la mesure des $\delta^{13} \mathrm{C}$ du $\mathrm{CO}_{2}$ (Fig. 8). Les protocoles expérimentaux correspondant peuvent être trouvés dans [13, 14, 15, 30].

\section{RESULTATS ET MODELISATION}

Les observations montrent une grande homogénéité dans la nature des minéraux rencontrés à l'échelle régionale. Les constantes d'échange ionique correspondent à celles attendues pour des argiles de types illite et smectite [22, 23, 29, 30]. La composition isotopique du $\mathrm{CO}_{2}$ montre que la concentration de ce gaz dans l'eau de la formation est régulée de manière constante par l'équilibre entre la solution et les minéraux de la roche comme cela est prévu par Coudrain-Ribstein et al. [31]. En revanche les teneurs en $\mathrm{Cl}^{-}$chutent de 100 à 15 mmol/L en suivant un axe NE/SW (du forage EST312 au forage EST322) (Fig. 3). Cette variation s'accompagne d’une évolution des cations adsorbés (Fig. 4). Compte tenu du profil de concentration en $\mathrm{Cl}^{-}$du Dogger, on peut émettre l’hypothèse d'une entrée de solutions salées provenant du Trias par un système de failles situé au NE du forage EST312 et diffusant horizontalement au sein du Dogger (les gradients hydrauliques assez mal connus paraissent très faibles dans cette formation). Le Dogger influence nettement la chimie des eaux du COX.

Le modèle d'équilibre thermodynamique entre la solution, la minéralogie, les surfaces argileuses, et la $p \mathrm{CO}_{2}$ utilisant le code PHREEQC [32] et la base de données llnl.dat [33] a permis de calculer 
plusieurs compositions d'eau compte tenu d'hypothèses sur les valeurs de $p \mathrm{CO}_{2}$ mesurées. Le modèle de Coudrain-Ribstein et al., [31] ne fixant pas la $\mathrm{pCO}_{2}$ mais régulant ce paramètre par un assemblage de minéraux en équilibre avec la solution a été testé et donne de bons résultats (Tableau VII). Appliquée à une échelle régionale, la modélisation a permis de calculer la variabilité de la composition chimique des eaux (Fig. 8).

\section{CONCLUSION}

La méthode employée permet de définir la chimie des eaux sans estimation de paramètres. Cependant, différents modèles peuvent être testés compte tenu des informations géochimiques recueillies. Cela permet de donner une gamme de compositions relativement restreinte pour la chimie des eaux au niveau du laboratoire souterrain de Bure. Les variations de teneurs en $\mathrm{Na}$ et $\mathrm{Cl}$ suivant un axe NE/SW au sein de la formation sont imputables au Dogger. Il conviendrait de construire un modèle 2D rendant compte de cette dynamique de transport. 


\section{INTRODUCTION}

\subsection{Context of the study}

The French Agency for Nuclear Waste Management (ANDRA) is building an underground research laboratory (URL) in Bure (northeastern France) to study the disposal of radioactive waste in a deep clay formation. The main gallery is located in the Callovian-Oxfordian formation (COX) at an approximate depth of $490 \mathrm{~m}$. To assess the durability of materials (glass, stainless steel, concrete, engineered clay barrier, etc.) and determine the mobility of the radionuclides in the host rock formation, it is necessary to define the chemistry of the COX porewater. ANDRA has therefore drilled a series of boreholes in the vicinity of the URL (Fig. 1). Core drilling provides a vast amount of geochemical data. This paper presents a method enabling the modeling of the porewater chemistry. This method is applied at a regional scale and enables a proper description of the chemical conditions in the formation.

\subsection{Studying the geochemistry of clay systems}

Studying the water chemistry of an argillaceous formation is a challenging task. The recovery of undisturbed water samples by classical methods is almost impossible due to the low permeability and low water content. Recently developed techniques for water extraction (squeezing, leaching, special borehole with gas control) give valuable results that can be used to characterize the water chemistry. However, each of these techniques introduces experimental and analytical artifacts. A review of studies of the porewater chemistry of mudrocks and extraction techniques can be found in [1, 2]. The chemistry of porewater in clay systems is difficult to define for several reasons including the very low porewater content and its strong interactions with clay minerals. The physical interaction between water and minerals means that either high pressure must be used to recover water by squeezing, or long-term sampling must be done to recover water in special boreholes in URLs. The high pressures used for squeezing techniques can dissolve some minerals. Even for conservative anions like $\mathrm{Cl}$, squeezing techniques generate artifacts $[3,4]$. Sampling in special boreholes requires preventive 
measures. As the porewater slowly fills the borehole chamber (specifically drilled and/or stored under $\mathrm{N}_{2}$ to minimize the oxidation) [5, 6], it will degas and bacterial development can perturb the system [7]. The reducing conditions that prevail in such systems could be another major source of concerns. Oxidation might significantly modify the mineralogy and the porewater quality $[4,8]$. At the contrary, growing of anaerobic bacteria can strongly reduce the system [7].

\subsection{Development of the THERMOAR method}

In a preliminary step to the URL porewater recovering experiments, a strategy to characterize and model the geochemical system was developed within the framework of the THERMOAR project through an ANDRA-BRGM partnership. The method was first developed for Opalinus Clay (Switzerland, [9]). The first samples from Bure came from the EST205 borehole drilled on the URL site where the laboratory's auxiliary shaft has later been dug. Many additional samples from regional boreholes drilled later by ANDRA have been added to the original data set. Most of the geochemical data obtained by ANDRA on the formation have been used to define the porewater chemistry at a regional scale.

The construction of the thermodynamic model enables us to define the porewater chemistry and also to describe reaction pathways. With this tool, we are able to model perturbations (alkaline solution, oxidation, microbial disturbance, etc.). In the THERMOAR method, data for a complete set of physical and chemical parameters were obtained to constrain the model. The originality of this approach is that no parameters are estimated and all major mineral phases are taken into account. In the past, clay porewater models have generally prescribed a hypothetical $\mathrm{CO}_{2}$ partial pressure (e.g., the model developed by Bradbury and Baeyens for the Opalinus Clay formation (Switzerland) [10]). Beaucaire et al., [11] disregard 2:1 clay and ion exchange reactions in a model for the Boom Clay porewater. Another model for the Callovian-Oxfordian formation developed by Motellier et al., [12] includes ion exchanges for 3 types of sorption sites, but calculates the aqueous speciation partially and does not take into consideration $\mathrm{SO}_{4}{ }^{2-}$ content. 
After a short description of the geology of the area, the data are presented and used to constrain the models. As several options are possible, the results of a series of models are presented and the most realistic model for the URL was applied to the evolving chemical conditions observed northeast and southwest of the URL site.

\section{GEOLOGICAL SETTING}

The geology of the site is described in detail in [13]. The Eastern Paris Basin sedimentary formations slightly dip ( $\left(1\right.$ to $\left.2^{\circ}\right)$ to the West within a simple monocline related to subsidence of the central part of the basin. Except for major regional fault zones (the Bray, Vittel and Metz faults) and the Gondrecourt and Marne faults delimiting the area investigated by ANDRA (Fig. 1), there is very little evidence of deformation.

At Bure, the Callovian-Oxfordian (COX) argillite (conventionally referred to as C2) is about $130 \mathrm{~m}$ thick. Five lithostratigraphic units have been identified and labeled C2a, C2b1, C2b2, C2c and C2d, from base to top. The sedimentary series is primarily clayey in the bottom two-thirds, and becomes progressively siltier, and then increasingly calcareous towards the top. A remarkable sedimentary surface is associated with the maximum clay zone (MCZ, 489-486 m): the maximum flooding surface (MFS) of the Callovian-Oxfordian cycle. This cycle marks the transition from transgression at the base to a regression, which led to the installation of the Oxfordian carbonate platforms. The top of the clayey formation is located at a depth of around $417 \mathrm{~m}$, overlapped by $243 \mathrm{~m}$ of Middle and Late Oxfordian limestone, followed by 175 m of Kimmeridgian marl and limestone, capped by the Barrois limestone of Kimmeridgian age. The clayey formation is separated from the Dogger limestone by a regional paleo-erosion surface. Under the Dogger limestone or marl (Bathonian, Bajocian, Aalenian), the Lias is marl-rich and capped the Triassic formations (sandstone and evaporite).

Some levels in the Kimmeridgian, Oxfordian and Dogger limestone are permeable. In the last two formations, water productivity is low. The hydraulic gradient in the Dogger is known has low. The COX is considered as impermeable. The Lias is impermeable or an aquitard formation. The Triassic is known to contain brines. 


\section{MATERIALS AND METHODS}

\subsection{Origin of the core samples}

The location of the boreholes is shown in Fig. 1. Boreholes EST205, EST207, EST212 concern the URL and additional data were obtained on samples from the laboratory auxiliary access shaft (PAX). The distance from the URL to boreholes MSE101, EST312, EST322 is 12.5, 15.5 and $9 \mathrm{~km}$, respectively. They are located, respectively, NW, NE and SW of the URL. All of these boreholes and shafts are located in the same structural block. Borehole EST342 is located beyond the "Marne graben" and "Joinville graben” structural accidents. The depths of boreholes in figures 3 and 6 are normalized to depths corresponding to borehole EST205 (URL site). As the thicknesses are not identical at all locations, the correspondence of depths between boreholes is not perfect.

Borehole EST205 was drilled with an oil-based mud consisting of $80 \%$ (by volume) oil (gas-oil containing $0.4 \%$ aromatics $)$ and $20 \%$ brine $\left(\mathrm{CaCl}_{2}, 350 \mathrm{~g} / \mathrm{l}\right)$. The oil and brine mixture forms an emulsion whose high Ca content prevents swelling of the clay minerals. The addition of $\mathrm{CaCO}_{3}$ to the mud helps to obtain densities above 1.1 necessary for coring in clay formations. This type of drilling mud helped prevent the mechanical evolution of the core samples and the swelling of clay minerals. However, the brine imposed a very high $\mathrm{Cl}$ gradient, which contaminated the cores by diffusion. An immediate treatment of the cores eliminates the edges, which preserves the chemistry of the samples. This was done for a limited number of borehole EST205 samples. The authors do not recommend the use of Cl data published in [13] which are too high because of the contamination by the oil-based mud. (The same problem exists for borehole EST211). The samples from the shafts were air drilled without mud. The mud used for boreholes EST212, EST207, EST342, EST312, EST322, MSE101 was a common mixture of bentonite and polymers. No major contamination was detected for this last series of boreholes. 


\subsection{Physical and geochemical parameters}

The parameters used in the model are the following:

- Mineral identification and crystallinity of minerals;

- $\quad$ The total reduced capacity of the rock (TRC);

- Water content and argilite texture;

- $\quad$ Anion leaching;

- $\quad$ Cation exchange capacity (CEC) and adsorbed cation population;

- Ion exchange constants ( $\left.\mathrm{K}_{\mathrm{H} / \mathrm{Na}}, \mathrm{K}_{\mathrm{K} / \mathrm{Na}}, \mathrm{K}_{\mathrm{Ca} / \mathrm{Na}}, \mathrm{K}_{\mathrm{Mg} / \mathrm{Na}}, \mathrm{K}_{\mathrm{Sr} / \mathrm{Na}}\right)$;

- $\quad \mathrm{CO}_{2}(\mathrm{~g})$ partial pressure and isotopic signature of the gas.

The analytical techniques used to identify and characterize the minerals, measure the TRC, determine the water content and textural properties, the leaching of anions, the cation exchange capacity and the adsorbed cation population are detailed in [13]. The experimental protocol used to determine ion exchange constants has been published in [14]. The method used to obtain the $p \mathrm{CO}_{2}(\mathrm{~g})$ and the isotopic signature of the gas is presented in [15].

\section{EXPERIMENTAL AND MODELING}

\subsection{Experimental data}

\subsubsection{Identification and crystallinity of minerals}

An accurate modeling of the water-rock interactions takes into account all minerals present, even at trace levels, and requires a complete mineralogical analysis of the samples. Because several minerals can control the aqueous speciation of an element, it was also necessary to determine some crystallinity criteria. Indeed, any mineral having alteration figures or an unbalanced structural formula is not considered at equilibrium in the model. Table I lists all of the minerals found in the CallovianOxfordian Formation with their relative abundance, distribution, and information on their crystallinity. Table I also indicates whether the phase must be taken into account in the thermodynamic model. 


\subsubsection{Total reduced capacity of the rock (TRC)}

The TRC is an index of the redox potential of the rock. It represents its "oxidizability" and is expressed in term of mole of available electrons. The mean value for the formation is $4.7 \pm 1.3 \mathrm{meq} / \mathrm{g}$. Theses values are similar to those measured in the Opalinus Clay Formation, $4.8 \pm 0.9$ meq/g [16]. TRC values do not vary a lot in the clay formation. The lower values are mainly due to calcareous beds $(1.6 \mathrm{meq} / \mathrm{g})$. TRC is linked to the organic matter content and mainly to sulfide minerals and to a lesser extent to siderite. Conditions in the formation are clearly reducing. In the model, the redox potential can be imposed by pyrite.

\subsubsection{Water content and argilite texture}

The Callovian-Oxfordian Formation has a very low water content. Water content ranges from $6 \%$ to $9 \%$ (mass water content dry base). Low contents (1.5\%) correspond to levels rich in fine-grained carbonate cement. There is a very good correlation between high carbonate content (> $65 \%$ ) and very low water content $(<4 \%)$. At the regional scale, variations in water content seem to be insignificant (Table II).

The water in the clay is of four different types [17]:

- Interlayer water within the sheet structure of clay minerals. This water is strongly adsorbed;

- another strongly adsorbed water at the clay mineral surface is the (structured) water participating in the hydration shells of the cations (which locally balance the mineral surface charges);

- loosely-held water in the diffuse-layer, and;

- free water.

For geochemical purposes, it is convenient to distinguish only between "bound” water (which includes interlayer, strongly adsorbed and some diffuse layer waters) and "free” water (which includes not only Horseman's free water [17], but also some of the diffuse layer and surface-sorbed waters as well) [18]. Note that the concept of geochemical porosity has been developed for clay to take into account anionic repulsion due to the negatively charged surface of the clay. Anionic repulsion limits the access of 
anions to part of the porosity. Geochemical porosity is the porosity that is accessible to mobile anions (such as $\mathrm{Cl}$ or $\mathrm{Br}$, for example). In a carbonaceous rock, anionic repulsion is limited and anions have access to all of the porosity. This distinction between geochemical porosity and total porosity for argillaceous rock is approximate, however practical. Thus, it is possible to quantify the two types of water by measuring the specific wetted surface using water sorption isotherms ( $\mathrm{S}_{\mathrm{BET}}^{\mathrm{H} 2 \mathrm{O}}$ ) [19]. For the argilite, the "bound" water is estimated to be about 2 to 3 water layers thick. Knowing the $\mathrm{S}_{\mathrm{BET}}^{\mathrm{H} 2 \mathrm{O}}$ and the thickness of the water layer, the volume of "bound" water is estimated to be about $50 \%$ of the total water volume (Table III). The ionic concentrations can be calculated either with the total water content (TW) or only with the "geochemical porosity" (GP). The advantages of the "geochemical porosity” concept will be demonstrated in the next paragraph.

\subsubsection{Leaching of anions}

Leaching of ions is a classic technique to obtain $\mathrm{Cl}^{-}$and $\mathrm{Br}^{-}$(and, in some cases, $\mathrm{I}^{-}$and $\mathrm{SO}_{4}{ }^{2-}$ ) contents in clay porewater. Information concerning cations, aqueous silica, carbonates and fluorides is generally disturbed by the dissolution of minerals. When plotted, concentrations of leached conservative anions give straight lines as a function of the solid/liquid ratio of the batch systems. The dissolution of a mineral gives a hyperbole (Fig. 2), and the oxidation of rock samples produces scattered values.

The behavior of $\mathrm{SO}_{4}{ }^{2-}$ during the leaching experiments with a regression coefficient $\left(\mathrm{r}^{2}\right)$ of 0.997 shows a perfect conservative character. The experiments seem to be undisturbed by pyrite oxidation. The $\mathrm{Sr}$ concentration value indicates that celestite is not significantly dissolved during leaching. The $\mathrm{SO}_{4}{ }^{2-}$ concentrations obtained by leaching represent probably the maximum values present in the porewater. Examples of concentrations of $\mathrm{Cl}^{-}, \mathrm{Br}^{-}, \mathrm{SO}_{4}{ }^{2-}$ in the total water (TW) and in the geochemical porosity (GP) are given in table IV for borehole EST205 (external part of the samples immediately cut after drilling to avoid contamination). 
An interesting observation was made during the calculation of $\mathrm{Cl}^{-}$concentrations in TW and GP. If we know the $\mathrm{Cl}^{-}$concentration in $\mathrm{mg} / \mathrm{kg}$ of rock, we can calculate the $\mathrm{Cl}^{-}$concentration in the porewater. For the samples from the auxiliary shaft, the mean concentration of $\mathrm{Cl}^{-}$in the total porosity is $2.37 \times 10^{-2} \pm 1.22 \times 10^{-2} \mathrm{~mol} / \mathrm{L}$. If a distinction is made between the argillaceous layers and the carbonaceous layers (water content $<4 \%$ ), two mean TW concentration values are observed (table V). The $\mathrm{Cl}^{-}$concentration in the carbonaceous layers is about twice as great as in the argillaceous layers. If we consider that the concept of geochemical porosity is applicable only to the argillaceous layers, the $\mathrm{Cl}^{-}$concentration values in the two media are very similar. The $\mathrm{Cl}^{-}$content in the formation is rather homogenous at the URL site and a value of $3 \times 10^{-2} \mathrm{~mol} / \mathrm{L}$ can be used in the model.

The $\mathrm{Cl}^{-}$contents were determined for all of the boreholes (Fig. 3). $\mathrm{Cl}^{-}$concentrations were calculated in the geochemical porosity for the argillaceous layers and in the total porosity for the calcareous layers. Dogger porewater was sampled in the regional boreholes and the $\mathrm{Cl}^{-}$concentrations are given on Fig. 3, which shows the strong influence of this formation on the $\mathrm{Cl}^{-}$content in the CallovianFormation. The $\mathrm{Cl}^{-}$content varies with depth in borehole EST312. A straight line can be drawn from the Dogger at $110 \mathrm{mmol} / \mathrm{l}$ to the top of the formation at $40 \mathrm{mmol} / \mathrm{L}$. For borehole MSE101 and at the URL site, there is less vertical variation-between 50-60 and $30 \mathrm{mmol} / \mathrm{L}$. Although MSE101 is located northeast of the URL, no $\mathrm{Cl}^{-}$variations can be detected between the two locations. For the two boreholes located southwest of the site, the vertical variation is negligible (EST 322: $17 \pm 10 \mathrm{mmol} / \mathrm{L}$, EST342: $26 \pm 23 \mathrm{mmol} / \mathrm{L}$ ). There is, therefore, a regional variation with a decreasing concentration of $\mathrm{Cl}^{-}$from northeast to southwest.

One possible explanation for this might be that saline water migrates from the Triassic formation via a fault system located northeast of borehole EST312. Since there is a $\mathrm{Cl}^{-}$concentration gradient in the Dogger formation, diffusion or a very slow advection might explain the horizontal migration of $\mathrm{Cl}^{-}$. The Dogger clearly influences the chemistry of porewater in the Callovian-Oxfordian Formation. 


\subsubsection{Cation exchange capacity (CEC) and adsorbed cationic population}

At the URL (EST205/PAX data), the mean CEC of the Callovian-Oxfordian Formation is $17.4 \pm 6.1$ meq/100 g. The lowest values are measured in the more calcareous beds (2.1 meq/100 g) and the highest values in the $\mathrm{I} / \mathrm{S}_{\mathrm{R} 0}$ zone $(25.1 \mathrm{meq} / 100 \mathrm{~g}$ at $463.74 \mathrm{~m})$. The $\mathrm{I} / \mathrm{S}_{\mathrm{R} 1}$ (less rich in smectite) has a very stable average value of $16.1 \pm 0.6 \mathrm{meq} / 100 \mathrm{~g}$.

As Bradbury and Baeyens [10] pointed out, the adsorbed cation population is a reflection of the solution in equilibrium with the mineral assemblage. Exchange reactions are very rapid and adsorbed cations are immediately in equilibrium with the porewater. The proportion of exchangeable cations is, therefore, very useful information. At the URL site, the distribution of exchangeable cations slowly evolves. In addition to the $4 \%$ of exchangeable $\mathrm{Sr}^{2+}$, the adsorption sites are taken up mainly by 45.3 $\pm 1.6 \%$ of $\mathrm{Ca}, 25.0 \pm 2.1 \%$ of $\mathrm{Mg}, 17.7 \pm 1.9 \%$ of $\mathrm{Na}$, and $8.1 \pm 1.1 \%$ of $\mathrm{K}$.

Exchangeable Sr was not systematically determined at the regional scale. Only the concentrations of exchangeable K, Na, Mg, and Ca will, therefore, be discussed. No significant vertical variations were observed for the different boreholes. This is also true for EST312, which presents the major $\mathrm{Cl}$ evolution. From NE to SW, there are large variations in the exchangeable cation distribution (Fig. 4). $\mathrm{CaX}_{2}$ values are identical in borehole EST312 and in the URL (EST205/PAX), and $\mathrm{MgX}_{2}$ increases to the detriment of alkaline ions. For example, there is only half as much KX. Southwest of the URL site at borehole $\mathrm{EST322,} \mathrm{the} \mathrm{proportion} \mathrm{of} \mathrm{MgX}_{2}$ is identical to that at the URL, there is a greater proportion of $\mathrm{CaX}_{2}$ and only one-third as much $\mathrm{NaX}$. Borehole EST342, located beyond the Marne and Joinville fault systems, has a greater proportion of $\mathrm{NaX}$, to the detriment of $\mathrm{MgX}_{2}$.

Considering the ion exchange populations of the regional boreholes, we can conclude that, for the COX porewater:

- the proportion of Na decreases from NE to SW following the decrease of the $\mathrm{Cl}^{-}$content;

- the proportion of $\mathrm{K}$ also decreases, in a lesser extent, and; 
- Ca and Mg concentrations are stable considering the electroneutrality.

\subsubsection{Ion exchange constants $\left(K_{\mathrm{H} / \mathrm{Na}}, K_{\mathrm{K} / \mathrm{Na}}, K_{G T N H 4 \mid \mathrm{Na}}, K_{\mathrm{Ca} / \mathrm{Na}}, K_{\mathrm{Mg} / \mathrm{Na}}, K_{\mathrm{Sr} / \mathrm{Na}}\right)$}

The work of many authors $[9,10,12,19,21,22,23,25]$ shows that there is a large consensus that ion exchange reactions are essential if we wish to model the porewater chemistry of clay-rich formations. We therefore determined a complete set of ion exchange constants ( $\mathrm{K}_{\mathrm{GT}}$ HINa, $\mathrm{K}_{\mathrm{GT}} \mathrm{KINa}, \mathrm{K}_{\mathrm{GT}}$ NH4INa, $\mathrm{K}_{\mathrm{GT}}$ CalNa, $\mathrm{K}_{\mathrm{GT} \text { MgINa, }} \mathrm{K}_{\mathrm{GT} \text { SrlNa}}$ ) on the $<2 \mu$ m clay fractions using the Gaines-Thomas [24] approach. As opposed to $[12,26]$, which use $\mathrm{H}^{+}$, our cation of reference is $\mathrm{Na}^{+}$. This gives constants that can be compared to data presented in the other studies after formalism adaptation [28, 29].

For a detailed description of the following experimental method, see [14].

Batch experiments were done using the purified clay fraction $(<2 \mu \mathrm{m})$ from a sample (K119 at $476 \mathrm{~m})$ from borehole EST205. The clay (0.5 g) was equilibrated (72 h) with a solution (25 ml) of $\mathrm{Na}_{\mathrm{x}} \mathrm{A}_{1-\mathrm{x}} \mathrm{Cl}$ $5 \times 10^{-3} \mathrm{~mol} / \mathrm{L}\left(\mathrm{A}=\mathrm{K}\right.$ or $\left.\mathrm{NH}_{4}{ }^{+}\right)$or $\mathrm{Na}_{\mathrm{x}} \mathrm{B}_{0.5-\mathrm{x}} \mathrm{Cl} 5 \times 10^{-3} \mathrm{~mol} / \mathrm{L}(\mathrm{B}=\mathrm{Ca}, \mathrm{Mg}, \mathrm{Sr})$. The discrete variations of $\mathrm{x}$ enabled a progression of the ion exchange reactions. After separation (centrifuging and filtration), this first solution was analyzed and the equivalent fractions of aqueous species were determined. The clay was re-dispersed $(24 \mathrm{~h})$ in a concentrated solution of cobaltihexamine (4 g/l). After separation (centrifuging and filtration), this second solution was analyzed and the equivalent fractions of adsorbed species were calculated. During this calculation, the molar quantity of aqueous species remaining in the residual porewater (after the first centrifugation) was corrected. The equivalent fractions of aqueous and adsorbed Na and A (or B) were used to construct isotherms (Fig. 5).

Using the Gaines-Thomas approach [24], it is possible to calculate for the exchange sites $\mathrm{X}_{\mathrm{i}}^{-}$, the selectivity coefficient $\mathrm{K}_{\mathrm{GT} \text { MN }}^{\mathrm{i}}$ (eq. 1) for an exchange between two cations $\mathrm{M}$ and $\mathrm{N}$ of charge $\mathrm{m}^{+}$and $\mathrm{n}^{+}$respectively. $\mathrm{E}_{\mathrm{M}}$ and $\mathrm{E}_{\mathrm{N}}$ (eq. 2) are the equivalent fractions of the adsorbed species. In equation 2, $E C_{i}$ is the exchange capacity of the $\mathrm{X}_{\mathrm{i}}^{-}$sites.

$$
K_{G T M \backslash N}^{i}=\frac{\left(E_{M}\right)^{n}}{\left(E_{N}\right)^{m}} \frac{\left(N^{n+}\right)^{m}}{\left(M^{m+}\right)^{n}}
$$




$$
E_{M}=\frac{m\left[\left(X_{i}^{-}\right)_{m} M^{m+}\right]}{E C_{i}} \quad E_{N}=\frac{n\left[\left(X_{i}^{-}\right)_{n} N^{n+}\right]}{E C_{i}} \quad E C_{i}=E_{M}+E_{N}
$$

\section{[...]: Concentration of adsorbed species}

Isotherm data are processed from equation (1) using a non-linear regression [27]. By modeling the $\mathrm{Na} / \mathrm{K}$ isotherm, we were able to identify illite-type and smectite-type sites. For the Opalinus Clay, a similar fit was done with 2 types of sites [14]. However, in this study, the global approach considering the ion exchange sites as a whole was tested for the modeling of porewater in neutral conditions. Therefore, in this paper, only the global constants are given in table VI.

\subsection{7 $\mathrm{CO}_{2(g)}$ partial pressure and isotopic signature of the gas}

The most original component of the THERMOAR project is the direct analysis of $\mathrm{CO}_{2}$ partial pressure on core samples [30]. The core samples were placed in a rigid container immediately after they had been drilled and the edges sawed off. Then the container was filled with an inert gas $\left(\mathrm{N}_{2}, \mathrm{He}\right.$, or $\left.\mathrm{Ar}\right)$. The results are slightly different, depending on the inert gas used. The best results were obtained when the initial total pressure in the container was sufficiently high $\left(\mathrm{P}_{\mathrm{tot}}>800 \mathrm{mbar}\right)$. The temperature and pressure in the cell were monitored continuously. The container was placed in a ventilated cupboard thermostated at a temperature of $25^{\circ} \mathrm{C}$. The gases released from the container were analyzed by gas chromatography until the $\mathrm{pCO}_{2}$ stabilized. At this point, analyses of $\mathrm{CO}_{2}$ isotopes were done [15].

The mean $\mathrm{pCO}_{2}$ values for the reference borehole EST205 are between 3.10 and 7.17 mbar (Log $\left.p C O_{2}:-2.51 /-2.15\right)$. These results are in the range of data compiled by Coudrain-Ribstein et al., [31] for sedimentary confined aquifers ( 1 to 100 mbar at $25{ }^{\circ} \mathrm{C}$ ). Fig. 6 presents the data obtained at a regional scale in the best analytical conditions $\left(\mathrm{P}_{\text {tot }}>800\right.$ mbar). Values range between 1.4 and 4.1 mbar ( $\left.\log \mathrm{pCO}_{2}:-2.9 /-2.4\right)$. No variation as a function of depth or at the regional scale can be observed. This can be a good indication of an internal control of this parameter by the mineralogy, the 
nature of which is constant throughout the formation. The isotopic composition of the gas confirms this. It shows (Fig. 7) that the $\mathrm{CO}_{2}$ has an original isotopic composition independent of the mantle, the atmosphere, organic matter or bacterial activity. Considering the gas $\delta^{13} \mathrm{C}$ values, we were able to determine the isotopic composition of the bicarbonate ions at equilibrium with the gas. The values are between -2 and $+2 \%$. The $\delta^{13} \mathrm{C}$ signatures of the bicarbonates and the carbonate cements of the clay rocks (mainly calcite and some dolomite and siderite) are similar. This proves that the $\mathrm{pCO}_{2}$ is controlled by the mineralogical assemblage (carbonates) and not by degradation of organic matter or diffusion of gas coming from others geological formations.

\subsection{Modeling porewater chemistry at a regional scale}

\subsubsection{Introduction}

In the Callovian-Oxfordian Formation, the nature of the mineralogy and the $\mathrm{pCO}_{2}$ regulation mechanisms can be considered as invariable at a regional scale. As the nature of the clay is also stable, the exchange selectivity coefficients can be used for the entire formation. The regional variation of the porewater chemistry was observed for $\mathrm{Cl}^{-}$and the ion exchange population. The model was initially constructed to define the porewater chemistry at the URL and, in a second step, was adapted to regional variations.

\subsubsection{Constrains to model the porewater at the URL}

Due to the stability of the mineralogy and the geochemical data, the porewater chemistry was considered to be constant in the clay formation at the URL location. All calculations were done at thermodynamic equilibrium. Due to the very low permeability of the clay formation and the probable residence time of the water, it is realistic to suppose that thermodynamic equilibrium can be reached in these geological media. The numerical model of the porewater chemistry involves two steps. First, seawater is diluted by pure water, and then the resulting water is equilibrated with the mineralogical assemblage and the exchange sites (X) of the clay. The dilution is defined so as to obtain the $\mathrm{Cl}^{-}$ concentration determined in §4.1.4. The entire mineral assemblage (§4.1.1) controls the following 
elements: e- $, \mathrm{S}, \mathrm{C}, \mathrm{Si}, \mathrm{Ca}, \mathrm{Mg}, \mathrm{Na}, \mathrm{K}, \mathrm{Sr}, \mathrm{Fe}, \mathrm{Al}$. Concerning the mineralogy, some simplifications have been considered: Pure phases (dolomite and siderite) and end members for chlorite solid-solution (Daphnite [Fe] and Clinochlore [Mg]) have been introduced in the modeling, in place of the observed minerals. Some geochemical subsystems can be distinguished in the model. Na is only determined by ion exchange ( $\mathrm{NaX})$. A subsystem Fe, $\mathrm{S}, \mathrm{e}^{-}, \mathrm{Sr}$, accounts for daphnite (Fe-Chlorite), celestite, pyrite, and ion exchange $\left(\mathrm{SrX}_{2}\right)$. A subsystem $\mathrm{Si}, \mathrm{Al}, \mathrm{K}$ is determined by quartz, illite, and ion exchange (KX). A subsystem $\mathrm{C}, \mathrm{Ca}, \mathrm{Mg}$, is controlled by $\mathrm{pCO}_{2}$, calcite, and dolomite. The ion exchange equations for $\mathrm{Ca}$ and $\mathrm{Mg}$ are considered in the equation system. However, they are not the determining factors for the water chemistry. They can only adjust the distribution of cations on the exchanger. The $\mathrm{pH}$ is calculated by iteration to obtain electroneutrality of the solution.

The calculations are performed with the PHREEQC code [32] using the llnl.dat database [33]. Three cases are presented in table VII. The simulations use the $\mathrm{Cl}^{-}$concentrations determined in the geochemical porosity. "A" simulation uses the maximum measured $\mathrm{pCO}_{2}$ value and "B" simulation, a value in the best analytical range (§4.1.7). "Chlo" corresponds to test cases where the $\mathrm{pCO}_{2}$ is not fixed. Mg-chlorite was added to the phase assemblage as in the model of Coudrain-Ribstein et al., [31]. In this model, the $\mathrm{pCO}_{2}$ is not controlled externally and is determined by the equilibrium between calcite, dolomite, and the Mg-Chlorite.

\subsubsection{Results: Composition of the porewater at the URL}

Erreur ! Source du renvoi introuvable. shows that the solutions are relatively concentrated with an ionic strength of $10^{-1} \mathrm{~mol} / \mathrm{L}$. The $\mathrm{pH}$ values are between 7.00 and 7.28. The Eh values are low (-176 $\mathrm{mV}<\mathrm{Eh}_{\mathrm{SHE}}<-156 \mathrm{mV}$ ). The waters have a $\mathrm{Cl} / \mathrm{SO}_{4}$ facies. Na is twice as concentrated as Ca and $\mathrm{Mg}$ and four times as concentrated as $\mathrm{K}$. The alkalinity is moderate, between 1 and $3 \mathrm{mmol} / \mathrm{kg}_{\mathrm{w}}$. The Al and Si contents agree with a system controlled by silicates and aluminosilicates. The Fe contents (determined by the equilibrium with daphnite) are quite high. However, the model calculates a quasi equilibrium with siderite, which has been found in places in the formation. The $\log p \mathrm{CO}_{2}$ value calculated with the "Chlo" model (-1.96) is similar to the maximum measured $\log p \mathrm{CO}_{2}$ values $(-2.15)$. 
This is a good indication that the model converges to a representative chemistry. Another possible verification is the proportion of adsorbed cations that are accounted for by model. The Table VII shows that the results are close to the measured values. On the contrary, if microcline is tested in the model instead of illite, the percentage of adsorbed cations is significantly different. This indicates that this phase does not participate in the regulation of the porewater chemistry.

\subsubsection{Modeling porewater at the regional scale}

To model the porewater at a regional scale, the "B” model described in $§ 4.2 .2$ was adjusted using the $\mathrm{Cl}^{-}$concentrations obtained for boreholes EST312 and EST322 (§4.1.4). The corresponding adsorbed ion concentrations are considered in the model (§4.1.5). Erreur! Source du renvoi introuvable. shows the evolution of the porewater chemistry, which is related mainly to a decrease in salinity ( $\mathrm{NaCl}$ ) from NE to SW in the structural block in which the URL is located. The decrease is of about 1 order of magnitude for the $\mathrm{Cl}$ and $\mathrm{Na}$ concentrations. The other concentrations are determined by the mineralogy and do not evolved significantly.

\section{CONCLUSIONS}

The THERMOAR method enables a detailed characterization of the geochemistry of the COX. The data set is complete and a model can therefore be developed without any estimated parameters. The different models presented in this paper for the ANDRA URL give an indication of the range of variation that can be calculated for the porewater chemistry. At the regional scale, the $\mathrm{Cl}^{-}$contents change as well as the adsorbed cations. It was also possible to model the porewater chemistry for the different regional boreholes. The challenge is now to model the transport of a saline porewater originating in the northeast and migrating horizontally in the Dogger Formation and then vertically and probably slowly in the Callovian-Oxfordian Formation.

The porewater chemistry model will also enable us to interpret future data obtained experimentally, directly in the ANDRA underground research laboratory. 


\section{AKNOWLEDGEMENT}

This work was funded within the framework of the ANDRA - BRGM partnership (THERMOAR

project 1998-2005). We thank H. Rebours (ANDRA/EST) and the ERM team (Poitiers) for their contributions. The reviews of Dr Pierre de Cannière (CEN/SCK, Belgique) and of Dr Gilles Berger (CNRS, France) have been very helpful. 


\section{REFERENCE}

[1] A.H. Bath, F.J. Pearson, A. Gautschi, H.N. Waber, Water-rock interactions in mudrocks and similar low permeability material, in: R. Cidu (Ed.), Proc. of the $10^{\text {th }}$ Inter. Symp. on Water-Rock Interaction, Villasimius, Sardinia, A.A. Balkema, Rotterdam, 2001, vol.1, pp. 3-12.

[2] E. Sacchi, J.-L. Michelot, H. Pitsch, Porewater extraction from argillaceous rocks for geochemical characterisation. Methods and interpretation. OECD/NEA, Paris, Report 662000 02, 2000.

[3] A.M. Fernández, A. Bath, H.N. Waber, T. Oyama, Water sampling by squeezing drillcores, in : F.J. Pearson et al. (Eds), Geochemistry of water in the Opalinus Clay Formation at the Mont Terri Rock Laboratory, Federal Office for Water and Geology, Geology Series, n5, Bern, 2003, pp. 171199.

[4] A.M. Fernández, R. Campos, M.D. Sánchez, M. Sánchez, A. Quejido, M.J. Turrero, J. Peña, E.C. Gaucher, Analysis of the pore water chemistry obtained by squeezing from rock samples of the Meuse Haute-Marne underground laboratory (France), Appl. Clay Sc. (2006) (submitted).

[5] L. Griffault, C. Bauer, H.N. Waber, F.J. Pearson, T. Fierz, A. Scholtis, C. Degueldre, L. Eichinger, Water sampling and analyses for boreholes and seepages, in : F.J. Pearson et al. (Eds), Geochemistry of water in the Opalinus Clay Formation at the Mont Terri Rock Laboratory, Federal Office for Water and Geology, Geology Series, n5, Bern, 2003, pp. 142-170.

[6] A. Vinsot, T. Fierz, C. Cailteau, P. de Donato, J. Pironon, P. Wersin, P. de Cannière, H.E. Gäbler, N. Badertscher, L. Eichinger, Gas equilibration and pore water sampling experiment in the Opalinus Clay at the Mont Terri Rock Laboratory, Proc. Clays in Natural \& Engineered Barriers for Radioactive Waste Confinement, 2nd Inter. Meeting, March 14-18, Tours, France, 2005, pp. 233-234. 
[7] P. Wersin, A. Gautschi, A. Vinsot, P. de Cannière, P. Hernan, H.E. Gäbler, K. Hama, Y. Mahara, E. Gaucher, Results from the Porewater Chemistry (PC) experiment at Mont Terri, Switzerland, in: R.B. Wanty, R.R. Seal II (Eds.), Proc. of the $11^{\text {th }}$ Inter. Symp. on Water-Rock Interaction, Saragota Springs, New York, USA, A.A. Balkema, New York, 2004, vol.1, pp. 523-526.

[8] M. De Craen, M. Van Geet, L. Wang, M. Put, High sulphate concentrations in squeezed Boom Clay pore water: evidence of oxidation of clay cores, Physics and Chemistry of the Earth, Parts A/B/C, 29 (2004) 91-103.

[9] F.J. Pearson, D. Arcos, J.-Y. Boisson, A.M. Fernandez, H.-E. Gäbler, E. Gaucher, A. Gautschi, L. Griffault, P. Hernan, H.N. Waber, Geochemistry of water in the Opalinus Clay Formation at the Mont Terri Rock Laboratory, Federal Office for Water and Geology, Geology Series, n5, 2003.

[10] M.H. Bradbury, B. Baeyens, A physicochemical characterisation and geochemical modelling approach for determining porewater chemistries in argillaceous rocks, Geochimica et Cosmochimica Acta, 62 (1998) 783-795.

[11] C. Beaucaire, H. Pitsch, P. Toulhoat, S. Motellier, D. Louvat, Regional fluid characterisation and modelling of water-rock equilibria in the Boom clay Formation and in the Rupelian aquifer at Mol, Belgium, Applied Geochemistry, 15 (2000) 667-686.

[12] S. Motellier, J. Ly, L. Gorgeon, Y. Charles, D. Hainos, P. Meier, J. Page, Modelling of the ion-exchange properties and indirect determination of the interstitial water composition of an argillaceous rock. Application to the Callovo-Oxfordian low-water-content formation, Applied Geochemistry, 18 (2003) 1517-1530.

[13] E. Gaucher, C. Robelin, J.-M. Matray, G. Negrel, Y. Gros, J.-F. Heitz, A. Vinsot, H. Rebours, A. Cassabagnere, A. Bouchet, ANDRA underground research laboratory: Interpretation of the mineralogical and geochemical data acquired in the Callovian-Oxfordian Formation by investigative drilling, Physics and Chemistry of the Earth, Parts A/B/C, 29 (2004) 55-77. 
[14] E. Gaucher, A. Cailleau, L. Griffault, Specific determination of ion exchange constants: the Opalinus Clay example, in : R. Cidu (Ed.), Proc. of the $10^{\text {th }}$ Inter. Symp. on Water-Rock Interaction, Villasimius, Sardinia, A.A. Balkema, Rotterdam, 2001, vol 2, pp. 1331-1334.

[15] J.-P. Girard, C. Flehoc, and E. Gaucher, Stable isotope composition of $\mathrm{CO}_{2}$ outgassed from cores of argillites: a simple method to constrain $\delta^{18} \mathrm{O}$ of porewater and $\delta^{13} \mathrm{C}$ of dissolved carbon in mudrocks, Applied Geochemistry, 20 (2005) 713-725.

[16] H.N. Waber, E. Gaucher, A.M. Fernandez, A. Bath, Aqueous leachates and cation exchange properties of Mont Terri claystones, in : F.J. Pearson et al. (Eds), Geochemistry of water in the Opalinus Clay Formation at the Mont Terri Rock Laboratory, Federal Office for Water and Geology, Geology Series, n5, Bern, 2003, pp. 200-237.

[17] S.T. Horseman, J.J.W. Higgo, J. Alexander, J.F. Harrington, Water, gas and solute movement through argillaceous media, Clay Club (Ed.), OECD/NEA, Paris, Report CC-96/1, 1996.

[18] F.J. Pearson, What is the porosity of a mudrock?, in : A.C. Aplin, A.F. Fleet, and J. Macquaker, (Eds), Muds and mudstones: Physical and fluid flow properties, 158, Geological Society Special Publication, London, 1999, pp. 9-21.

[19] H. Gaboriau, A. Seron, A. Saada, F. Villiéras, L. Griffault, Characterization and distribution of porewater in low permeable clayey formations: contribution of physical methods, in: R. Cidu (Ed.), Proc. of the $10^{\text {th }}$ Inter. Symp. on Water-Rock Interaction, Villasimius, Sardinia, A.A. Balkema, Rotterdam, 2001, vol 2, pp. 1327-1330.

[20] D.C. Thorstenson, D.W. Fisher, M.G. Croft, The geochemistry of the fox Hills-Basal Hell Creek aquifer in the southwestern North Dakota and the northwestern South Dakota, Water Resour. Res., 15 (1979) 1479-1498.

[21] L.N. Plummer, F.F. Bubsy, R.W. Lee, B.B. Hanshaw, Geochemical modeling of the Madison aquifer in part of Montana, Wyoming and South Dakota. Water Resour. Res., 26 (1990) 1981-2014. 
[22] C.A.J. Appelo, A. Willemsen, H.E. Beekman, and J. Griffioen, Geochemical calculations and observations on salt water intrusions. II. Validation of a geochemical model with laboratory experiments, Journal of Hydrology, 120 (1990) 225-250.

[23] L. Griffault, T. Merceron, J.-R. Mossmann, B. Neerdael, P. de Canniere, C. Beaucaire, S. Daumas, A. Bianchi, R. Christen, Acquisition and regulation of the water chemistry in clay environment. Project “Archimède”, CEC final report EUR 17454, Science and nuclear techniques, Luxembourg, 1997.

[24] L.G. Gaines, C.H. Thomas, Adsorption studies on clay minerals. II. A formulation of the thermodynamics of exchange adsorption, Journal of Chemical Physics, 21 (1953) 714-718.

[25] K. Walraevens, J. Cardenal,. Preferential pathways in an Eocene clay: Hydrogeological and hydrogeochemical evidence, in: A.C. Aplin, A.F. Fleet, and J. Macquaker, (Eds), Muds and mudstones: Physical and fluid flow properties, 158, Geological Society Special Publication, London, 1999, pp.175-186

[26] P. Jacquier, J. Ly, and C. Beaucaire, The ion-exchange properties of the Tournemire argillite: I. Study of the H, Na, K, Cs, Ca and Mg behaviour, Applied Clay Science, 26 (2004) 163-170.

[27] D.W. Marquardt, An algorithm for least squares estimation of parameters, J. of the Soc. of Indust. and Appl. Math., 11 (1963) 431-441.

[28] C. Thellier, and G. Sposito, Quaternary cation exchange on Silver Hill illite, Soil Science Society of America Journal, 52 (1988) 979-985.

[29] P. Fletcher, and G. Sposito, The chemical modeling of clay/electrolyte interactions for montmorillonite., Clay Minerals, 24 (1989) 375-391.

[30] E.C. Gaucher, A. Lassin, J.-P.Girard, C. Crouzet, C. Flehoc, E. Proust, C. Poinclou,. A new analytical method to constrain the partial pressure of $\mathrm{CO}_{2}$ in mudrocks, Appl. Geoch., (2006) in prep. 
[31] A. Coudrain-Ribstein, P. Gouze, G. de Marsily, Temperature-carbon dioxide partial pressure trends in confined aquifers, Chemical Geology, 145 (1998) 73-89.

[32] D.L. Parkhurst, C.A.J. Appelo, User's guide to PHREEQC (Version 2). A computer program for speciation, batch-reaction, one-dimensional transport, and inverse geochemical calculations, U.S.G.S. (Ed.), Water-resources investigations report 99-4259, Denver, 1999.

[33] T.J. Wolery, EQ3/6, a software package for geochemical modeling of aqueous systems: Package overview and installation guide. Lawrence Livermore National Laboratory, Livermore, California, version: thermo.com.V8.R6.230, 1992. 


\section{Tables}

\begin{tabular}{|c|c|c|c|c|}
\hline Mineral & Abundance & $\begin{array}{l}\text { Depth at the URL } \\
\text { location }\end{array}$ & Crystallinity & $\begin{array}{l}\text { Insertion in the } \\
\text { modeling }\end{array}$ \\
\hline Illite & +++ & ever-present & good, Fe-rich & yes \\
\hline Interlayered I/S $\mathrm{S}_{\mathrm{R} 0}$ & +++ & $>493.4 \mathrm{~m}$ & good & yes \\
\hline Interlayered I/S $\mathrm{S}_{\mathrm{R} 1}$ & +++ & $<489.2 \mathrm{~m}$ & good & yes \\
\hline Glauconite & trace & no systematic & $?$ & no \\
\hline Kaolinite & + & $<453.7 \mathrm{~m}$ & good & can be tested \\
\hline Montmorillonite & ++ & $\begin{array}{l}\text { special level at } \\
425.03-425.08\end{array}$ & good & can be tested \\
\hline Chlorite (Chamosite) & trace & ever-present & various Fe-content & yes \\
\hline Biotite & trace & no systematic & chloritised & no \\
\hline Muscovite/Phengite & trace & no systematic & detrital & no \\
\hline Microcline/Orthoclase & trace & no systematic & good, detrital & can be tested \\
\hline Albite/plagioclase & very rare & very rare & detrital, alteration figures & no \\
\hline Quartz & +++ & ever-present & good, detrital figures & yes \\
\hline Chalcedony & trace & no systematic & good & can be tested \\
\hline Calcite & +++ & ever-present & $\begin{array}{l}\text { good, several } \\
\text { crystallizations }\end{array}$ & yes \\
\hline Aragonite & trace & no systematic & good & no \\
\hline Ca-rich Dolomite & ++ & ever-present & good & yes \\
\hline Ankerite/Siderite & ++ & ever-present & good & yes \\
\hline Celestite & trace to ++ & ever-present & good & yes \\
\hline Pyrite & + & ever-present & polymorph, good & yes \\
\hline Sphalerite/Chalcopyrite & very rare & very rare & $?$ & no \\
\hline Native Sulfur & very rare & very rare & very small particle & no \\
\hline Rutile/Anatase & trace & ever-present & good & no \\
\hline Apatite/Collophane & trace & no systematic & $?$ & no \\
\hline
\end{tabular}

Table I: $\quad$ Synthesis of the mineralogical data gathered for the Callovian-Oxfordian formation.

Tableau I : $\quad$ Synthèse des données minéralogiques obtenues pour la formation du Callovo-Oxfordien.

\begin{tabular}{lcc}
\hline Borehole & Water content (\%) & Standard error (\%) \\
\hline EST312 NE & 8.04 & 1.34 \\
\hline EST205 URL & 7.03 & 1.80 \\
\hline EST212 URL & 6.62 & 0.92 \\
\hline EST207 URL & 6.73 & 1.00 \\
\hline EST322 SW & 5.54 & 2.09 \\
\hline EST342 SW & 5.57 & 1.98 \\
\hline \multicolumn{1}{c}{ Table II: } & $\begin{array}{l}\text { Mean values of mass water content (\%) in the } \\
\text { Tableau II : }\end{array}$ & $\begin{array}{l}\text { Callovian-Oxfordian formation at the regional scale } \\
\text { Valeurs moyennes (\%) des teneurs massiques en eau } \\
\text { de la formation du Callovo-Oxfordien à l'échelle } \\
\text { régionale. }\end{array}$
\end{tabular}




\begin{tabular}{ccccc}
\hline $\begin{array}{c}\text { Est205 } \\
\begin{array}{c}\text { Sample \& Depth } \\
(\mathrm{m})\end{array}\end{array}$ & $\begin{array}{c}\mathrm{H}_{2} \mathrm{O} \text { Specific Surface } \\
\left(\mathrm{m}^{2} / \mathrm{g}\right)\end{array}$ & $\begin{array}{c}\text { Total water content } \\
(\mathrm{g} / 100 \mathrm{~g}) \\
(\mathrm{dry} \text { base })\end{array}$ & $\begin{array}{c}\text { Free water } \\
(\mathrm{g} / 100 \mathrm{~g}) \\
\text { (dry base) }\end{array}$ & $\begin{array}{c}\text { free water } \\
(\%)\end{array}$ \\
\hline $\mathrm{K} 1004$ size: $10,6 \AA$ & 6,13 & 3,79 & 61,8 \\
$\mathrm{~K} 108447 \mathrm{~m}$ & 30,0 & 6,28 & 3,50 & 55,8 \\
$\mathrm{~K} 113462 \mathrm{~m}$ & 35,6 & 6,18 & 3,34 & 54,1 \\
$\mathrm{~K} 119477 \mathrm{~m}$ & 36,0 & 8,98 & 4,60 & 51,3 \\
\hline
\end{tabular}

Table III: $\quad$ Results of $\mathrm{H}_{2} \mathrm{O}$ specific surface and calculation of the $\%$ of free water.

Tableau III : $\quad$ Résultats de surface spécifique à l'eau et calcul du \% d'eau libre.

\begin{tabular}{lccccccc}
\hline $\begin{array}{l}\text { EST205 } \\
\text { Sample }\end{array}$ & $\begin{array}{c}\text { Depth } \\
(\mathrm{m})\end{array}$ & \multicolumn{2}{c}{$\begin{array}{c}\mathrm{Cl}^{-} \\
(\mathrm{mol} / \mathrm{L})\end{array}$} & \multicolumn{2}{c}{$\begin{array}{c}\mathrm{Br}^{-} \\
(\mathrm{mol} / \mathrm{L})\end{array}$} & \multicolumn{2}{c}{$\begin{array}{c}\mathrm{SO}_{4}{ }^{2-} \\
(\mathrm{mol} / \mathrm{L})\end{array}$} \\
\hline & & $\mathrm{TW}$ & $\mathrm{GP}$ & $\mathrm{TW}$ & $\mathrm{GP}$ & $\mathrm{TW}$ & $\mathrm{GP}$ \\
$\mathrm{K} 100424 \mathrm{~m}$ & $423.68-424.48$ & $1.79 \times 10^{-2}$ & $2.90 \times 10^{-2}$ & $3.2 \times 10^{-5}$ & $5.1 \times 10^{-5}$ & $5.17 \times 10^{-2}$ & $8.35 \times 10^{-2}$ \\
K119 477m & $476.57-476.97$ & $1.54 \times 10^{-2}$ & $3.01 \times 10^{-2}$ & $3.4 \times 10^{-5}$ & $6.5 \times 10^{-5}$ & $3.22 \times 10^{-2}$ & $6.28 \times 10^{-2}$ \\
\hline
\end{tabular}

Table IV:

Concentrations of $\mathrm{Cl}^{-}, \mathrm{Br}^{-}, \mathrm{SO}_{4}{ }^{2-}$ in the total of the porosity (TW) and in the geochemical porosity (GP) calculated from leaching experiments.

Tableau IV: $\quad$ Concentrations de $\mathrm{Cl}^{-}, \mathrm{Br}^{-}, \mathrm{SO}_{4}{ }^{2-}$ dans la porosité totale (TW) ou dans la porosité géochimique (GP) calculées à partir des expériences de lessivage.

\begin{tabular}{lccc}
\hline Rock & $\begin{array}{c}\text { Anions accessible } \\
\text { Porosity (Geochemical } \\
\text { porosity concept) }\end{array}$ & $\begin{array}{c}\mathrm{Cl}^{-} \text {Concentration in the } \\
\text { total porosity } \\
\text { (TW) } \\
(\mathrm{mol} / \mathrm{L})\end{array}$ & $\begin{array}{c}\mathrm{Cl}^{-} \text {Concentration in the } \\
\text { geochemical porosity } \\
(\mathrm{GP}) \\
(\mathrm{mol} / \mathrm{L})\end{array}$ \\
\hline Carbonates & $100 \%$ & $3.48 \times 10^{-2} \pm 1.96 \times 10^{-2}$ & $3.48 \times 10^{-2} \pm 1.96 \times 10^{-2}$ \\
Argilites & $50 \%$ & $1.65 \times 10^{-2} \pm 5.80 \times 10^{-3}$ & $3.61 \times 10^{-2} \pm 1.68 \times 10^{-2}$ \\
\hline
\end{tabular}

Table V: $\quad$ Comparison of calculated concentrations of $\mathrm{Cl}$ in the calcareous and argillaceous layers as a function of the accessible porosity.

Tableau V : $\quad$ Comparaison des concentrations en $\mathrm{Cl}$ calculées au sein des bancs argileux ou calcaires en fonction de l'accessibilité de la porosité.

\begin{tabular}{cccc}
\hline Model 1 type of sites & Constant & $\begin{array}{c}\text { Standard } \\
\text { Deviation }\end{array}$ & $\log _{10}$ Constant \\
\hline HNa & 13,0 & 2,63 & 1,11 \\
KINa & 2,78 & 0,12 & 0,44 \\
NHAlNa & 2,98 & 0,14 & 0,47 \\
CalNa & 3,17 & 0,10 & 0,50 \\
MglNa & 2,41 & 0,09 & 0,38 \\
SilNa & 4,75 & 0,19 & 0,68
\end{tabular}

Table VI: $\quad$ Callovian-Oxfordian Formation (fraction $<2 \mu \mathrm{m}$ ). Gaines-Thomas constants for a global type of exchange sites.

Tableau VI : Formation du Callovo-Oxfordien (fraction $<2 \mu \mathrm{m}$ ). Constantes de Gaines-Thomas pour un type global de sites d'échange. 


\begin{tabular}{|c|c|c|c|}
\hline Model & $\mathbf{A}$ & B & Chlo \\
\hline Porewater chemistry & $\mathrm{mol} / \mathrm{kg}_{\mathrm{w}}$ & $\mathrm{mol} / \mathrm{kg}_{\mathrm{w}}$ & $\mathrm{mol} / \mathrm{kg}_{\mathrm{w}}$ \\
\hline $\mathrm{pH}$ & 7,10 & 7,28 & 7,00 \\
\hline $\mathrm{Eh}_{\mathrm{SHE}}(\mathrm{mV})$ & -163 & -176 & -156 \\
\hline Alk & 1,97E-03 & 1,29E-03 & 2,46E-03 \\
\hline Ionic strength & $1,16 \mathrm{E}-01$ & $1,16 \mathrm{E}-01$ & $1,17 \mathrm{E}-01$ \\
\hline $\mathrm{Cl}$ & $3,01 \mathrm{E}-02$ & 3,01E-02 & 3,01E-02 \\
\hline S & 3,39E-02 & $3,40 \mathrm{E}-02$ & 3,39E-02 \\
\hline $\mathrm{Na}$ & 3,21E-02 & $3,20 \mathrm{E}-02$ & $3,21 \mathrm{E}-02$ \\
\hline $\mathrm{K}$ & 7,09E-03 & 7,07E-03 & $7,10 \mathrm{E}-03$ \\
\hline $\mathrm{Ca}$ & 1,49E-02 & $1,48 \mathrm{E}-02$ & $1,50 \mathrm{E}-02$ \\
\hline $\mathrm{Mg}$ & 1,41E-02 & $1,41 \mathrm{E}-02$ & $1,42 \mathrm{E}-02$ \\
\hline $\mathrm{Sr}$ & 1,12E-03 & 1,12E-03 & $1,12 \mathrm{E}-03$ \\
\hline Si & 9,41E-05 & 9,43E-05 & $9,40 \mathrm{E}-05$ \\
\hline $\mathrm{Al}$ & 7,36E-09 & $8,62 \mathrm{E}-09$ & 6,85E-09 \\
\hline $\mathrm{Fe}$ & $2,14 \mathrm{E}-04$ & 9,40E-05 & 3,32E-04 \\
\hline \multicolumn{4}{|c|}{ saturation index (si) } \\
\hline $\log \left(p C O_{2(g)}\right)$ bar & $-2,15 *$ & $-2,51^{*}$ & $-1,96$ \\
\hline si_Illite & 0 & 0 & 0 \\
\hline si_Montmor-Ca & $-0,177$ & $-0,143$ & $-0,195$ \\
\hline si_Microcline & 0,5581 & 0,652 & 0,509 \\
\hline si_Calcite & 0 & 0 & 0 \\
\hline si_Dolomite & 0 & 0 & 0 \\
\hline si_Fe-Chlorite & 0 & 0 & 0 \\
\hline si_Quartz & 0 & 0 & 0 \\
\hline si_Siderite & 0,0906 & $-0,235$ & 0,261 \\
\hline si_Pyrite & 0 & 0 & 0 \\
\hline si_Celestite & 0 & 0 & 0 \\
\hline si_Gypsum & $-0,0085$ & $-0,0086$ & $-0,0085$ \\
\hline si_Mg-Chlorite & 0,85 & 2,48 & 0 \\
\hline \multicolumn{4}{|c|}{ ion exchange } \\
\hline $\mathrm{SrX}_{2}$ & $4 \%$ & $4 \%$ & $4 \%$ \\
\hline $\mathrm{KX}$ & $8 \%$ & $8 \%$ & $8 \%$ \\
\hline $\mathrm{NaX}$ & $14 \%$ & $14 \%$ & $14 \%$ \\
\hline $\operatorname{MgX}_{2}$ & $28 \%$ & $28 \%$ & $28 \%$ \\
\hline $\mathrm{CaX}_{2}$ & $45 \%$ & $45 \%$ & $45 \%$ \\
\hline
\end{tabular}

Table VII: Model results (PHREEQC, llnl.dat). Various test cases of porewater chemistry: $\mathrm{Cl}^{-}$concentration in the geochemical porosity, "A" simulation use the maximum measured $\mathrm{pCO}_{2}$ value and "B" a $\mathrm{pCO}_{2}$ value in the best analytical range, "Chlo" corresponds to test cases where the $\mathrm{pCO}_{2}$ is not fixed. In this model, the $p \mathrm{CO}_{2}$ is determined by the equilibrium between calcite, dolomite, and Mg-chlorite.

Tableau VII : Résultats de modélisations (PHREEQC, llnl.dat): Différents cas tests pour la chimie de l'eau interstitielle : Concentration en $\mathrm{Cl}^{-}$dans la porosité géochimique, la simulation "A" utilise la valeur mesurée de $p \mathrm{CO}_{2}$ maximum, "B" utilise la valeur de $\mathrm{pCO}_{2}$ obtenue dans les meilleures conditions analytiques, "Chlo" correspond à un cas test où la $p \mathrm{CO}_{2}$ n’est pas fixée. Dans ce dernier modèle, la $p \mathrm{CO}_{2}$ est déterminée par équilibre avec la calcite, la dolomite et une chlorite-Mg. 
Figures

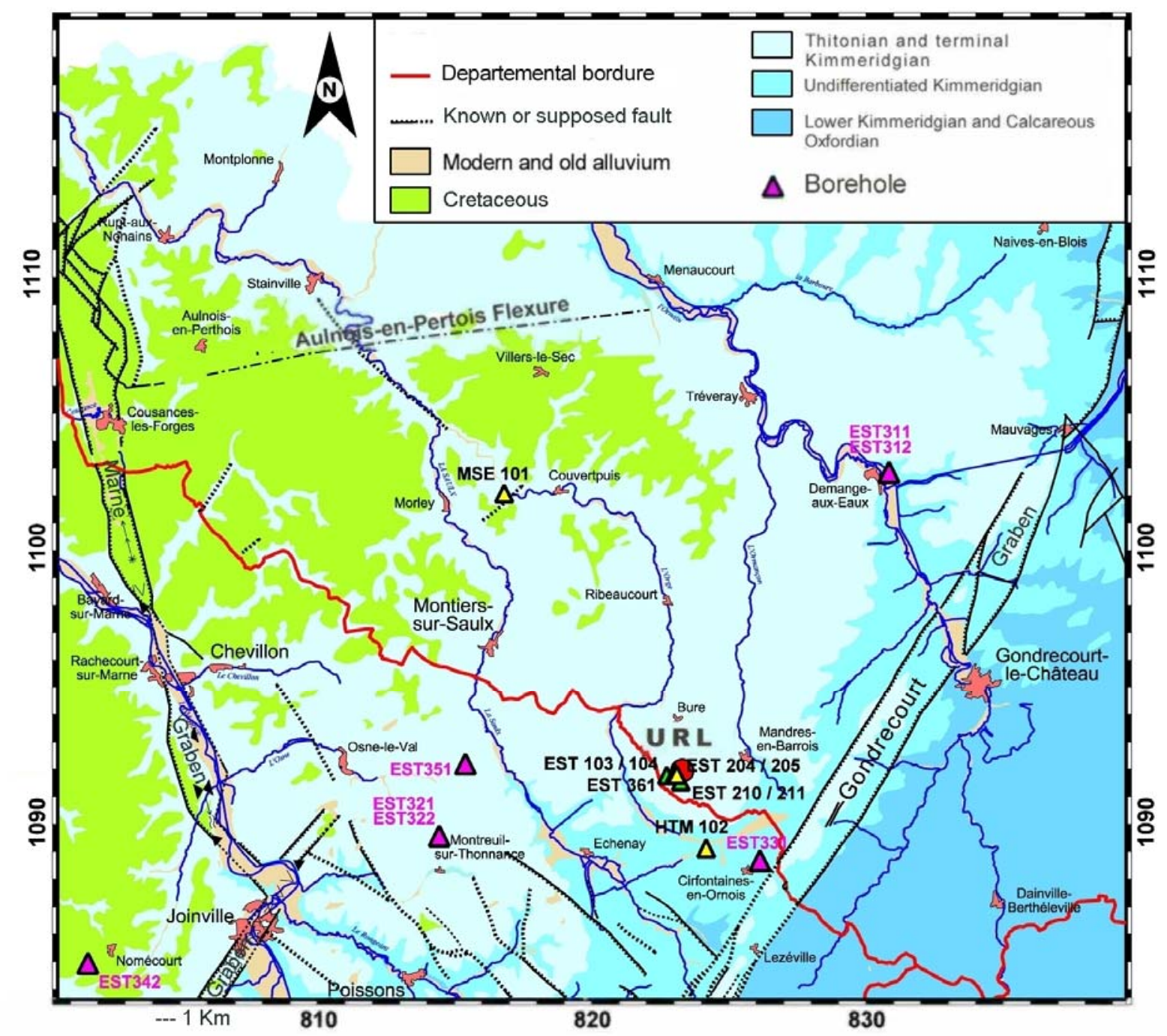

Fig. 1:

Geological map of the study area with location of the Bure underground research laboratory (ANDRA URL) and regional boreholes. (Lambert Coordinates)

Fig. 1: $\quad$ Carte géologique de la zone d'étude avec implantation du laboratoire souterrain de l'ANDRA (URL) et des forages régionaux. (Coordonnées Lambert) 


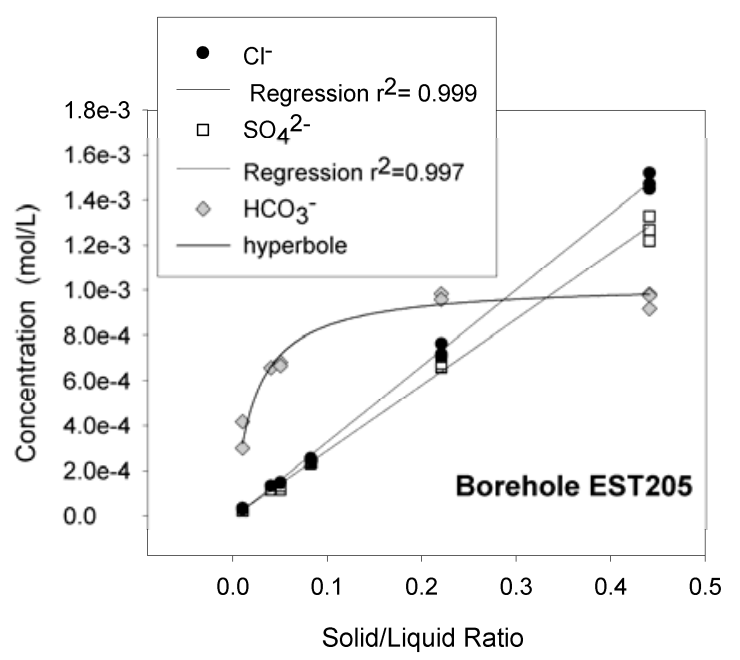

Fig. 2: $\quad$ Leaching experiments. Concentrations of leached $\mathrm{Cl}^{-}, \mathrm{SO}_{4}{ }^{2-}$, $\mathrm{HCO}_{3}^{-}$vs. the solid/liquid ratio. The regression lines are calculated. The hyperbolic behavior of $\mathrm{HCO}_{3}{ }^{-}$shows its nonconservative character compared to $\mathrm{Cl}^{-}$and $\mathrm{SO}_{4}{ }^{2-}$.

Fig. 2: $\quad$ Expériences de lessivage. Concentrations en $\mathrm{Cl}^{-}, \mathrm{SO}_{4}{ }^{2-}, \mathrm{HCO}_{3}{ }^{-}$ lessivés en fonction du rapport solide/liquide. Les droites de régressions sont calculées. La forme hyperbolique de la courbe de $\mathrm{HCO}_{3}{ }^{-}$illustre le caractère non conservatif de l'ion par comparaison avec $\mathrm{Cl}^{-}$et $\mathrm{SO}_{4}{ }^{2-}$. 


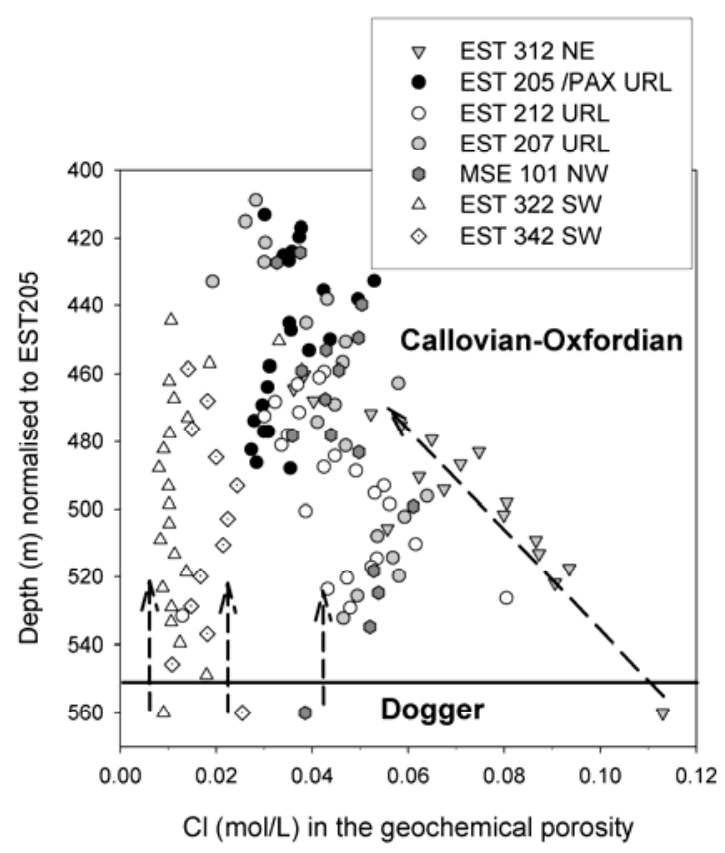

Fig. 3:

Dogger porewater influence on the $\mathrm{Cl}^{-}$concentration in the geochemical porosity of the Callovian-Oxfordian Formation at a regional scale.

Fig. 3: $\quad$ Influence des eaux interstitielles du Dogger sur la concentration en $\mathrm{Cl}^{-}$dans la porosité géochimique au sein de la Formation du Callovo-Oxfordien à une échelle régionale. 


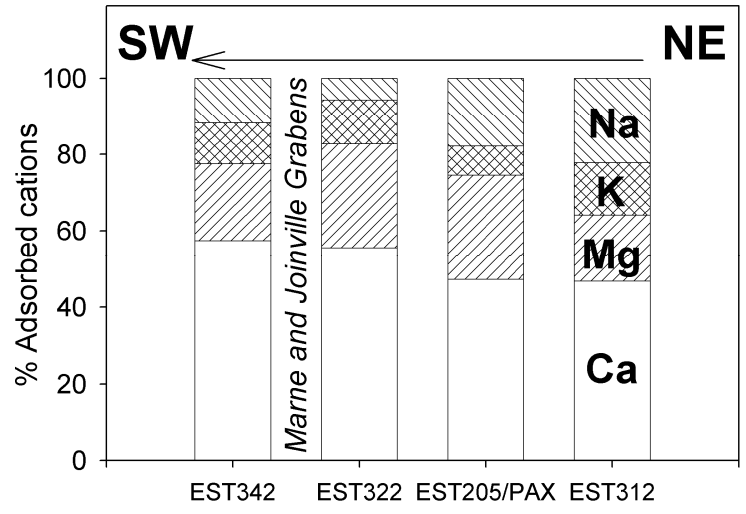

Fig. 4: $\quad$ Variation in the proportion of adsorbed cations from northeast (EST $312 \mathrm{NE}$ ) of the URL (EST205/PAX) to southwest (EST 322 and EST 342, SW).

Fig. 4: $\quad$ Evolution de la proportion des cations adsorbés du nord-est (EST 312 NE) du laboratoire souterrain (EST205/PAX) au sud-ouest (EST322 et EST 342, SW) 


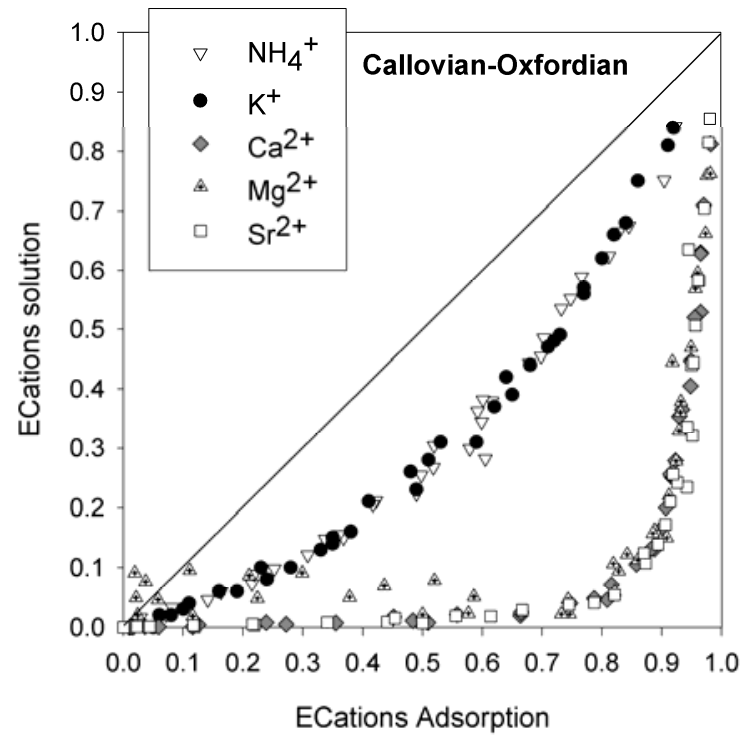

Fig. 5: $\quad$ Ion exchange data: $\mathrm{Na}^{+} / \mathrm{NH}_{4}^{+}, \mathrm{Na}^{+} / \mathrm{K}^{+}, \mathrm{Na}^{+} / \mathrm{Ca}^{2+}, \mathrm{Na}^{+} / \mathrm{Mg}^{2+}$, $\mathrm{Na}+/ \mathrm{Sr}^{2+}$. Clay fraction $(<2 \mu \mathrm{m})$ of core $\mathrm{K} 119(476.5 \mathrm{~m})$ EST205 (URL)

Fig. 5: $\quad$ Données d'échange d'ions: $\mathrm{Na}^{+} / \mathrm{NH}_{4}^{+}, \mathrm{Na}^{+} / \mathrm{K}^{+}, \mathrm{Na}^{+} / \mathrm{Ca}^{2+}$, $\mathrm{Na}^{+} / \mathrm{Mg}^{2+}, \mathrm{Na}+/ \mathrm{Sr}^{2+}$. fraction argileuse $(<2 \mu \mathrm{m})$ carotte $\mathrm{K} 119$ (476.5 m) EST205 (Laboratoire souterrain) 


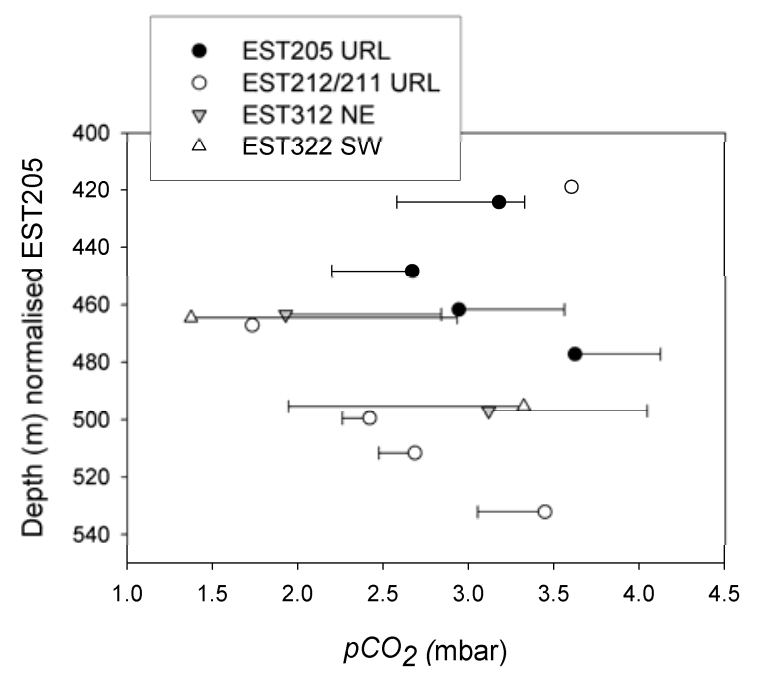

Fig. 6: $\quad \mathrm{CO}_{2}$ partial pressure obtained by degassing of core samples from northeast (NE) to southwest (SW) of the URL. The points are the final values of the experiments. The error bars correspond to the extreme values measured under the most favorable analytical conditions $\left(P_{\text {tot }}>\right.$ 800 mbar).

Fig. 6: $\quad$ Pression partielle de $\mathrm{CO}_{2}$ obtenues par dégazage des carottes du nordest (NE) au sud-ouest (SW) du laboratoire souterrain. Les points sont les valeurs finales de l'expérience. Les barres d'erreurs correspondent aux valeurs extrêmes mesurées dans les meilleures conditions analytiques $\left(P_{\text {tot }}>800\right.$ mbar $)$. 


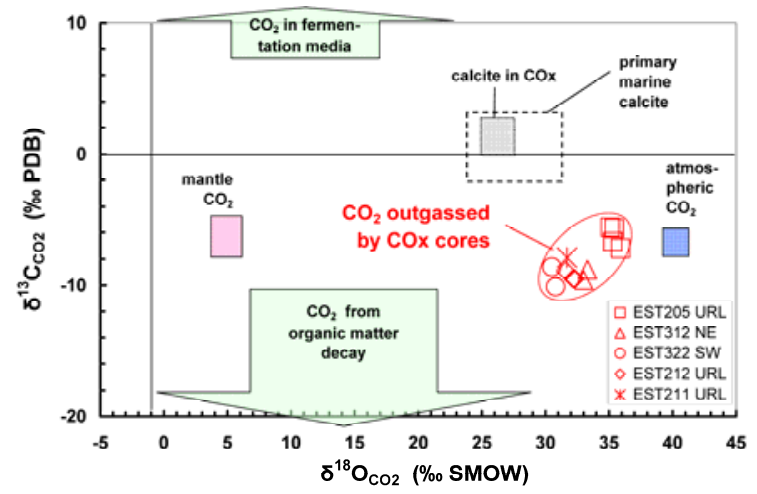

Fig. 7: Isotopic composition of $\mathrm{CO}_{2}$ obtained by degassing of core samples from northeast (NE) to southwest (SW) of the URL. Comparison with various sources of $\mathrm{CO}_{2}$ and with the isotopic compositions of calcites of the formation. Isotopic References: PDB: Peedee formation Belemnite, U.S.A ; SMOW: Standard Mean Ocean Water.

Fig. 7: $\quad$ Composition isotopique du $\mathrm{CO}_{2}$ obtenu par dégazage des carottes $\mathrm{du}$ nord-est (NE) au sud-ouest (SW) du laboratoire souterrain. Comparaison avec diverses sources de $\mathrm{CO}_{2}$ et avec les compositions isotopiques des calcites de la formation. Références isotopiques : PDB : Bélemnite de la formation de Peedee, U.S.A ; SMOW : Standard Mean Ocean Water. 


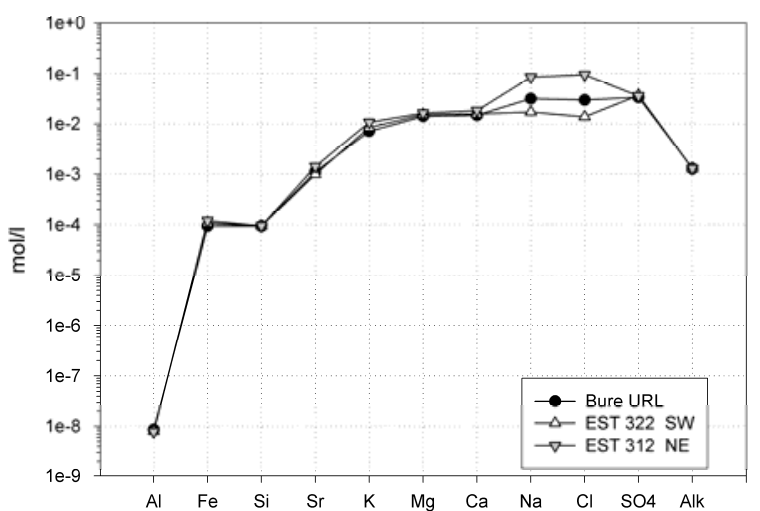

Fig. 8: Schoeller diagram: Porewater chemistry modeling. Comparison of " $B$ " model (URL) with the models developed for EST312 (NE) and EST322 (SW).

Fig. 8: $\quad$ Diagramme de Schoeller: Modélisation de la chimie des eaux interstitielles. Comparaison du modèle «B» (Laboratoire souterrain) avec les modèles réalisés pour EST312 (NE) et EST322 (SW). 
